\title{
Does Europe Really Have a Unique Role?
}

\author{
Christopher Stevens
}

For the EEC Commissioner for Development Cooperation, Edgard Pisani, there is no doubt about the answer to the question posed in the title. 'Development policy', he has claimed, 'is a cornerstone of European integration'. Why? Because 'it is a manifestation of Europe's identity in the world at large and a major plank in the Community's external policies generally...' [EEC 1982a:1]. This implies that development policy is good for Europe, because it promotes Community spirit and allows the Ten to present a united front to the world at large. But is it good for the Third World? Is there anything that the European Community does, or could do, that the member states acting alone could not achieve?

The articles in this Bulletin set out to identify areas for an EEC initiative. All are based upon papers presented to a conference held at the IDS in June 1982 on the theme of 'Europe and the South in the 1980s: Prospects for Political Change'. ${ }^{1}$ Most have since been revised substantially, to take account both of the comments made at the conference, and of the effects of subsequent events. All of them take it as given that there will continue to be a set of Community-level policies on North-South issues, in addition to policies established at a member-state level. This is almost certainly a realistic expectation, at least for the rest of this decade. But there remains plenty of scope for nuances within this bifurcated overall approach: Community-level policy can be increased or decreased in scale $v i s-\grave{a}$-vis national-level policy. Commissioner Pisani has already made a move to extend his role. $\mathrm{He}$ has, for instance, proposed - and the Commission (although not the member states) has accepted - that the volume of Community-level aid should be doubled to 1 per cent of EEC GNP, if necessary simply by increasing the proportion of European aid that is channelled through the Community institutions [EEC 1982a:42]. Yet, at the same time, the Community's North-South policy is under threat. On the trade front, growing pressure for nationally-based non-tariff barriers (NTB) to imports threatens to undermine Community-level policies. As far as aid is concerned, at a time of stagnant or falling disbursements, there is

'The conference was financed by the European Commission's Directorate-General for Information (DG 10). growing competition between different outlets; Denmark's contribution to Community aid, for example, has come mainly at the expense of the UNDP [Svendsen 1983].

Given these options, it is worth going back to first principles and asking whether the South has anything to gain from a unification of European North-South policy and, related to this, whether the Community has special features which give it a comparative advantage in undertaking certain types of activity.

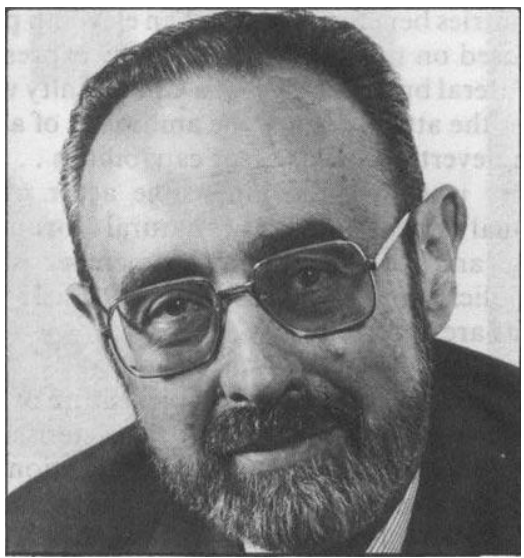

Pisani has proposed that the volume of Community-level aid should be doubled to one per cent of EEC GNP.

\section{Characteristics of a Community Posture Fundamentals}

There are two levels at which the characteristics of the Community's current stance on North-South issues and its potential can be discussed. First, there are questions about the inherent features of a Communitylevel position: what is it that the EEC can do precisely because it is a Community that the member states and bodies such as the World Bank and the UN agencies cannot do? Second, there is the more prosaic level of tactical realities: are there ways the EEC can act which are not open to member states simply because of how things happen to be organised? 
Comment has tended to concentrate on the second, tactical, level of analysis. Probably this is not because of any failure by commentators to appreciate the importance of strategy. Rather, it is a reflection of the absence of anything much to say at the strategic level. There are remarkably few features of current Community policy that set it apart, fundamentally, from what is being done elsewhere by others. Even the most radical proposals for the future tend to concentrate on shifting onto a pan-European basis, policies that are already being implemented by one or more of the member states, or which could equally be organised on a Community or a national basis. Hence the Commission's proposal to use the European Monetary System to foster monetary stability in the African, Caribbean and Pacific (ACP) signatories of the Lomé Convention [EEC 1982a:44], has the air of an extension of the long-established franc zone in West Africa.

The Commission has made brave, attempts to establish the unique credentials of an EEC approach to the Third World. "Community development policy', it has asserted, 'is distinct from the member states' bilateral policies, and is seen as a separate entity by the countries benefiting. It is not an eleventh policy superimposed on the ten others. It is the expression, not multilateral but collective, of a Community which has neither the attributes nor the ambitions of a state but which nevertheless has great capabilities ... The Community is seen as a responsible actor on the international stage and as a natural forum for concerting and coordinating the member states' national policies and positions' [EEC 1982a:15]. But such claims are hard to justify.

In practice, possibly the most tangible feature of EEC policy that can reasonably be characterised as uniquely Communautaire, is its predilection for regional groupings. As Reg Green has remarked elsewhere [Green 1983], 'birds of a feather flock together', and this has been a starting point for a dialogue between the EEC and the Southern African Development Coordinating Conference (SADCC). The EEC's preferences are evident in its network of formal relations with the Third World. The Lomé Convention is the most obvious example of this. Ever since Lomé I was signed in 1975 with 46 (now 63) ACP states, the EEC has tended to sing its praises to three melodies: its contractual nature, its package of aid and trade, and its uniqueness as an agreement between two regional groups. So proud is the Community of Lomé, that it has been reluctant to spend the aid that it has earmarked for Angola and Mozambique, the two remaining independent Black African states that are not signatories, and it has exerted considerable pressure to persuade them to join the 'Lomé III' talks. But Lomé is not the only example of the EEC's predilection for regional pacts. It is the most fully developed only because the Community has been unwilling to accord a similar range and depth of preferences to other, more competitive, countries. The desire to establish a single agreement with the Mediterranean region is of long-standing. The goal is as far removed as ever, but as a first step the Commission has proposed that Europe should 'arrive swiftly at a position on the broad outlines of the Mediterranean policy which it feels it should promote in the future' [EEC 1982b:19]. The eventual aim is for 'a global convention between the two regions, along the lines of the Lomé Convention ... (which) would balance relations and so make them less vulnerable to sectoral or immediate economic difficulties' [EEC 1982b:17].

Elsewhere, the EEC has organised its bilateral pacts with the ASEAN states within an overall framework agreement. While the framework agreement has little substance of its own, it does appear to have fostered a political commitment, as evidenced by the annual foreign ministers' meetings which are star-studded affairs; no less than seven European foreign ministers attended the 1983 gathering in Bangkok. Similar framework agreements are being touted for South Asia and the Andean Pact countries, and the decision at the end of 1982 to provide additional aid to Central America marks the beginning of a move to consider this area as a single region (with possible implications for Europe's links with the Caribbean).

Within Lomé and some of the other agreements, there are aid tranches specifically earmarked for regional projects. The record on implementation has not been particularly brilliant. By the end of 1981 the ratio of disbursements to commitments for regional projects financed from the Lomé I aid package was almost 19 per cent lower than the average for all projects, which itself was lamentably low. Total spending on regional projects was less than disbursements made, for example, to Senegal and Guinea-Bissau together. But these figures may paint too gloomy a picture. The EEC has played a useful role, for example, in acting as a financial midwife at the birth of SADCC.

If this tendency towards regionalism is a hallmark of Community action, is it a good thing? Given the problems caused by disunity among developing countries, the answer to this question might appear self-evident: anything that fosters unity has something to be said for it. The first Lomé Convention negotiations were marked by a welcome breaking down of barriers bet ween anglophone and francophone African states, and this unity has since been institutionalised in the organisations spawned by the Convention, most notably the ACP committee of ambassadors and the ACP secretariat. 
But the unity fostered by the EEC is of a very partial and idiosyncratic variety. Europe selects the regional groups with which it will deal on the basis of perceptions of its own self-interest. Sometimes, this produces an overlap with an existing association of developing countries, as in the Caribbean basin where, for example, the EEC has recognised the existence of Caricom in its negotiations for sugar purchases (in contrast to the USA which, in its Caribbean Basin Initiative, has tended to undermine existing regional groups). ${ }^{2}$ Sometimes, however, there is no such overlap and the EEC may be a divisive influence. The Arab League has complained, for instance, of Europe's practice of dividing its members into four groups - the Maghreb, the Mashreq, the ACP, and the rest (mainly the Gulf) - none of which has any real meaning outside Community parlance.

The same applies at a global level, where the EEC's regionalism is accused of undermining Third World unity. This charge is given added bite by the fact that the favours accorded by the EEC to some states are in practice preferences over other Third World states. Thus the ACP countries are given a veto, in practice if not in theory, over extensions to the EEC's generalised system of preferences (GSP), to ensure that other Third World states do not improve their relative position. More fundamentally, some actors within the Community regard Lomé not simply as a pragmatic accord but as a model for a future organisation of world economic relations to replace the principles of universality and non-discrimination established after World War II. The Commission's major restatement of development policy in 1982 affirmed that Lomé is a precursor of a more fully developed set of agreements that will replace the traditional framework of relations between nation states ... with a system of relations between regional groups or major continental units basing their relations on the predictability and security of a contract ...' [EEC 1982a:31]. Too much should not be read into such statements of principle that probably have little chance of being translated into practice, at least overtly. It should be recalled that when the Lomé Convention was signed, it was accompanied by dark murmerings of neo-colonialism, and attacked as a ploy to bind Africa more closely to Europe's coat tails in an essentially exploitative relationship. ${ }^{3}$ In the face of Lomé's failure to produce any very substantial effect, for good or ill, such criticism has subsided of late, even though recent analysis of trade flows under Lomé I has shown that Europe has done better than have the ACP states [Moss 1983]. Nonetheless, this statement of Commission policy is very revealing of the philosophy that

${ }^{2}$ This comparison of the USA's Caribbean Basin Initiative and EEC policy is taken further in Blackburn and Merry [1983].

${ }^{3}$ Shaw [1979] provides an extensive review of the various positions from which Lomé has been analysed. underlies the advocacy of regionalism by some Community policy-makers.

\section{Superficials}

It seems, therefore, that there are few very substantial characteristics of a Community-level North-South policy to distinguish it from national policies. However, there are features of current Communitylevel policy that set apart from those of the member states in many small and a few large ways. Together with its propensity for regionalism, these provide a signpost for the direction in which EEC policy could move during the rest of the decade. But, at the same time, the bases of Community-level policy are under pressure.

Probably the most important feature of Community decision-making on North-South issues is the fact that, as Ramphal notes, within the Commission the Commissioner for Development Cooperation has a much higher profile than do any of the aid ministers in the member states. He is a fully fledged member of the Commission, equal in status to other Commissioners, whereas most national aid ministers are of noncabinet rank. The most important elements of the EEC's economic relations with the Third World are the common policies on trade and agriculture, and the partly common policy on aid. Largely because of the Lomé Convention, the Commissioner for Development Cooperation has a finger in each of these pies (albeit a rather small one in agriculture). Moreover, on trade matters, his quasi-ministry, DG 8 (the Directorate-General for Development), shares the field not with a department representing the interests of domestic industry, but with the DirectorateGeneral for External Relations (DG 1). The combination of this wide range of bona fide interests (however tenuous some of them may be in practice) and the Commissioner's 'cabinet' status gives him the potential to poke his nose into the whole range of North-South policies.

Furthermore, the overall orientation of the Commission is one that favours the type of positive action recommended by the 'mutual interests' school. Two such proposals are presented in this Bulletin by Lal Jayawardena and Alain Dangeard on financial recycling. They share a salient characteristic with all proposals of this kind in that they require Northern governments both to recognise a mutual interest and to act upon it. Unfortunately, in practice governments have a tendency to react to events rather than to take major initiatives. Not so the Commission; its mandate is precisely one of making proposals and taking initiatives to which the Council reacts.

This combination of factors - a high profile development minister, with a wide range of potential 
interests, and the Commission's mandate to take initiates - has produced some remarkably bold statements that would find considerable favour in the mutual interests school. In 1981, for example, in preparation for the Ottawa Western economic summit, it proposed a package of initiatives on energy (recognising both the need for more exploration, inter alia via a World Bank energy affiliate, and the need for conservation in the industrialised countries), on finance (including an increase in resources for the IMF and World Bank, new forms of resource transfer such as bonds, and inflation-proofing OPEC's financial assets as part of a programme to improve the stability of the financial system), on food and agriculture (which acknowledged the need for the EEC to alter its own practices) and, perhaps most significantly, on the need for Europe to restructure its own industrial and trade relations [EEC 1981].

Of course, such proposals are usually given fairly short shrift by the Council of Ministers. But, at a time of $\mathrm{d}$ windling official interest in the Third World, it is a modest plus for the Community that an organisation exists with a brief to put before the member states at regular intervals a broad programme that recognises that Europe is as much a cause of the problem as part of the solution. In this the Commission has, so far, been assisted by the European Parliament which has also taken a very broad view of North-South policy. Soon after its inauguration as an elected assembly it devoted the energies of five committees for the space of a year to pondering 'Hunger in the World', and produced a report recognising that the causes of hunger are far wider than, simply, the inadequate agricultural policies of developing countries, and that a number of the most potent have their origins in Europe's own policies. The Parliament's resolution [EEC 1980] recognises that the elimination of World Hunger implies 'far-reaching adjustments to the production methods and way of life in the industrialised countries' and 'a massive transfer of financial and technological resources to the leastfavoured regions and countries' (para 5). Hence, while it contains a long (and useful) catalogue of changes required in the developing countries, it also notes that 'the more advanced countries should adapt their commercial policies, above all as regards trade in food and other agricultural products, to developing countries' requirements' (para 63) and in particular 'requests the Commission to draw up a trade policy in the agricultural sector which would be compatible with the Community's development policy' (para 45), a request that has so far gone unheeded!

To set against these positive features of Community policy are some quite clear defects which affect in particular the more traditional aspects of Third World policy. The problems of the EEC aid programme can be summed up in the observation that it is 'designed by a committee', with all that this implies. Within the complicated aid structure the degree of Commission autonomy varies between one type of aid and another. It has most control (in the sense of relative autonomy and an administration that is relatively adequate for the task) in relation to the Lomé aid programme, and least in relation to food aid. As a result, food aid is often a shambles, but even Lomé aid is heavily constrained. Most aid agencies are responsible to some higher authority which must give its approval to proposed aid projects. In theory, the Commission is more independent that most since its "higher authority' for Lomé aid projects - the EDF Committee representing the Ten member states - can only express a view, not take a decision, on accepting or rejecting. In practice, however, the control exercised by the European Development Fund (EDF) Committee is particularly intrusive. Michael Lipton has noted that the Board of the World Bank has never rejected a project recommended to it by the Bank staff [Lipton 1983]. In the case of the EEC, by contrast, the views expressed by the EDF committee are rarely if ever ignored.

Moreover, the Commission is not its own master in ordering its house. The member states set the number of staff that can be employed and nominate the senior officials. The split in career structure between the officials of DG 8 and those of the delegations in the ACP states came about partly because of a deliberate attempt by the Commission to side-step the iron hand of the member states, and it has had unfortunate administrative consequences. The short truth is that DG 8 is too small to administer the aid programmes for which it is responsible in the manner in which it and the Council would like the programme to be administered. This statement begs several questions, of course: whether staffing would be adequate if the programme were administered in a different manner - for example, by giving the receiving countries greater freedom to decide on the detailed use of aid; or of whether DG 8 makes the most efficient use of the staff that it does possess. The point to note, however, is that the Commission's capacity to adapt itself so as to become an efficient aid agency is heavily constrained by factors outside its control.

Moreover, as Michael Lipton points out in his article, the scrutiny of implementation that is provided by the Court of Auditors, while 'useful in detecting graft or incompetence... is of little value in establishing the vital facts sought by project evaluation...' In view of the new thrust of EEC development policy, which is described in the next section, the conclusion that he draws from his catalogue of the EEC's administrative shortcomings is particularly relevant. The conclusion is that "lack of evaluation, let alone of a "lesson- 
learning" mechanism ... is especially damaging in rural development ... EEC aid suffers from being neither bilateral nor multilateral, neither centralised nor decentralised ... Rural projects ... are especially vulnerable to the resulting problems ....

\section{Directions for EEC policy in the 1980s}

The EEC Commission has sought to establish a new direction for its Third World policy in its memorandum of October 1982 [EEC 1982a], a document that is very closely linked with the Commissioner for Development Cooperation and, for this reason, is usually known as the 'Pisani Memorandum' ${ }^{4}$ The preceding section suggested that, apart from its regional orientation, the Commission's major asset is its broad view of North-South issues, and its greatest weakness is its relative ineffectiveness as an aid agency with problems that bear particularly heavily on rural development. Ironically, the thrust of the Pisani Memorandum, in a nutshell, appears to be an emphasis on the Commission's role as an aid agency, especially in the rural sector, with a neglect (relatively if not absolutely) of the broad picture.

The memorandum continues the practice of dividing the Third World into a hierarchy of zones among which Africa (and, to a lesser extent, the Caribbean and the Pacific) and the Mediterranean dominate. It is likely, therefore, that this new approach will make itself felt first in policies towards these regions and, in particular, in the year-long negotiations for a successor to Lomé II which commence in September 1983. The Commission has already proposed to the Council its views for the conduct of these negotiations.

A major feature of the Pisani Memorandum, as amplified in the proposed 'Lome III' mandate, is that aid should be better coordinated and more coherently focused on promoting what is called autonomous and self-centred development, in that all efforts, both industrial and agricultural, should be oriented in the first place to satisfying domestic demand. In respect of agriculture, therefore, the EEC is taking a stance that is clearly opposed to that of the Berg Report, ${ }^{5}$ and claims an affinity with the Lagos Plan [OAU 1981]. It is less certain, however, whether the same affinity with the Lagos Plan can be claimed in respect of industry. When combined with the Pisani Memorandum's reticence on the issue of European industrial restructuring (in contrast to earlier Commission documents) it sounds more like an attempt to head off ACP efforts to export manufactures to the EEC.

In their details, how do these documents measure up to the prescriptions made in this Bulletin? Ramphal

${ }^{4}$ For a further summary of the Pisani Memorandum proposals see ODI [1983] and Stevens [1983a, 1983b].

${ }^{5}$ See Allison [1983] for an assessment of the Berg Report. recognises that there is some truth in the EEC's view of itself as a bloc with particular interests at stake in the Third World. Given the negative posture of the current US Administration, he asks whether Europe has the will to take the action prescribed by its own rhetoric: "can Europe overcome its sense of dependency on the Americans at least in the interest of recalling the United States to its own tradition of compassion, generosity and internationalism?'. Commissioner Pisani would undoubtedly reply that it should do so, but it is not so clear that he would agree with other elements in the prescription. For, if Europe is to take the lead, Ramphal has no doubt that 'Europe-South cooperation cannot . . . be confined within the parameters of Lomé as it stands', and he warns that it "is not feasible to contemplate a regime of relations between Europe and the South in the 1980s ... which leaves North-South issues stagnating on the periphery, while Europe and the South - or parts of it - pursue the illusion of patchwork change'. Debt, protectionism, and the role of the IMF and World Bank are central concerns. ${ }^{6}$

The 1933 World Economic Conference came too late to avert the great depression; will the verdict of history on the failed GATT Ministerial of November 1982 be the same? Vincent Cable explains the results of selective protectionism on the UK economy using the Cambridge growth model. He uses the model to simulate the effect of import controls on textiles/clothing and vehicles. The conclusion is that 'the gain in output and employment accruing from selective protection of one industry will be offset in part or total by employment and output losses elsewhere in the economy'.

In contrast to this gloomy prospect, Ramphal recalls the imagination that inspired the Marshall Plan. A similar degree of imaginative self-interest is urged by Lal Jayawardena who puts forward a new system for recycling petrodollars. He proposes that the EEC should take advantage of the current soft oil market to introduce unilaterally an inflation-indexed security which would provide an attractive home for OPEC surpluses on one condition: that OPEC exercises restraint in its oil price increases. Linked to this he proposes a reciprocal offer by OPEC surplus countries to convert their oil price increases into concessional loans to oil-importing developing countries. Alain Dangeard addresses the same issue, and argues that the details of such recycling schemes matter less than their spirit which 'tries to make interdependence work

\footnotetext{
${ }^{6}$ There is no surer way to unpopularity in DG 8 than to compare its activities unfavourably with those of the World Bank which, together with the $1 \mathrm{MF}$, are known in Euro-speak by the code name 'financing bodies'. It is clearly to the World Bank that the Pisani Memorandum is referring when it caustically notes that 'one might be forgiven for thinking that the point of aid is not to put an end to intolerable hardships, but to fund the safest, most profitable investment" [EEC 1982a:7].
} 
in practice by providing each partner with an appropriate mix of incentives'. Instead of Jayawardena's recycling proposals, he suggests that European and OPEC investors should collaborate to finance sectoral priority programmes in developing countries which are identified through joint discussions with the host government. Such programmes 'should cover agricultural self-sufficiency, energy diversification, raw materials contribution to development and industrial development'.

This sectoral approach is much closer to the EEC Commission's views as expressed in the Pisani Memorandum and the Lomé mandate proposal, which seek a policy dialogue in the sectors of food and agriculture, energy, industry and minerals. So far, Community thinking is most fully developed in relation to the first of these sectors - food and agriculture. Michael Lipton welcomes Commissioner Pisani's new approach which, if it works (a big caveat) 'will constitute an enormous advance on earlier approaches to its relationship with the ACP states', and he 'seeks to clarify some of the issues and requirements facing any EEC programme to assist African countries in developing food strategies'. He concludes that 'Africa's increasing net food imports are its central development constraint, that growing hunger is its central poverty problem ...' and that the pressing need is for 'research-oriented strategies for high-income, low-risk, labour-intensive small farming'

The burden of the Commission's public thinking so far has been to question whether African governments can devise and adhere to such strategies. But what is equally germane to the question is whether the EEC can respond adequately when such strategies emerge. The Bible has something apposite to say about the relative attention to be given to 'motes' and 'beams' that impair the faculties. It might be objected that this puts the relative proportions the wrong way around: that while Europe has its faults they are mere motes compared to the beams that hinder African development. But this is only true if the discussion is limited to development cooperation narrowly defined, and even then the EEC's schoolmarmly lecturing strikes as presumptuous: it wags a finger at Africa's administrative failings, and then cannot deliver food aid within two years of when it was requested; it criticises inadequate African agricultural policies without even blushing at its own failures to devise a rational food policy.

If the discussion is broadened, the relative importance of the mote and beam change drastically. Edward Clay provides just such a broadening. He points a truth that is often overlooked by those who pronounce on the problems of hunger and poverty in the Third World: 'there is not so much a single problem of world hunger as related sets of problems which have different implications for policy at national and international levels'. While some EEC policies may provide a palliative, others are contributing directly to the problem. A major cause of food insecurity is that many more developing countries have become vulnerable to movements in the world economy because of structural changes in their agricultural and food sectors'. In its own attempt to achieve food security through the CAP, the EEC has thrust insecurity on to others: 'the external consequence of such policies as followed by the EEC . . . is that the burden of adjustment in world markets falls particularly heavily on the US livestock sector and on developing countries'.

While food is Commissioner Pisani's top priority, mining and energy have figured prominently in past negotiations with the ACP, and are likely to do so again in 1983. Mike Faber, Carlos Fortin and Adrian Hewitt review the experience of the various mining related instruments in Lomé II, such as Sysmin, and find that the record is disappointing. They propose three new initiatives that could be to the mutual benefit of both the EEC and the ACP. One is that a new scheme is required to promote exploration. Given that 'the wider the community of potential customers who undertake such funding the more certain are they collectively to reap the benefit' such schemes are 'in concept, singularly appropriate for Community initiatives'. Further, they identify the need for emergency purchases of minerals from selected ACP countries when prices are exceptionally low. This would not be a buffer stock scheme, but one 'to provide support to selected mineral producers in times of distress'. Finally, they support the concept of mineral revenue stabilisation funds backed by 'benign conditionality' and designed 'to provide insurance against an inability to maintain development programmes in periods of slump' and 'to regulate domestic demand stimulated by government expenditure by preventing such demand from building up in boom periods'. Francisco Parra provides additional thoughts about the nature of Third World energy problems and the most desirable focus for external assistance.

How well does all this analysis and advice marry with the views of the Pisani Memorandum? There is general support for sector strategies that provide more flexible, coherent and better-designed assistance, but these should not be at the expense of the broader elements of North-South relations. The Commission should not forget that perhaps its most tangible claim to uniqueness as far as the Third World is concerned is that it has Europe's only minister for North-South relations. 
One area in which these two levels of concern overlap, and where Europe could make a significant contribution concerns conditionality. Sector strategies, if they mean anything at all, imply a shift towards programme lending. The problem is that programme lending inevitably involves the lender in setting policy conditions. The conditionality imposed by the leading programme lender, the IMF, is of a particularly unpalatable variety for many developing countries, and they have been reluctant to accept IMF assistance as a result (although their severely deepening problems are now giving them little option). At its best, the Lomé relationship does provide a forum for a constructive dialogue in which new forms of sectoral conditionality could be hammered out. It takes two sides to conduct a dialogue, and it is not yet certain that the ACP will respond to Pisani's invitation. But they are more likely to do so if Commissioner Pisani has something to offer them, in the form of improvements in donor practice to complement any changes to which the recipients agree. At present he has rather little to offer them, partly because the Commission does not have the power to alter its practice. What is required is for the EEC to offer to remove the inefficiencies and rigidities in the aid it provides to sector strategies that have been agreed with the recipient. In many cases this will involve giving the recipient much greater discretion in using the aid, and reducing the scope of the member states to interfere. It is to the Council of Ministers, therefore, that we must look now, to see if it can respond constructively to the ideas thrown up by the Commission.

\section{References}

Allison, C. and R. H. Green, (eds), 1983, 'Accelerated development in sub-Saharan Africa', Bulletin, vol 14 no 1 , IDS, Sussex

Blackburn, L. and F. Merry, 1983, 'EEC and USA policies towards the Caribbean Basin' in C. Stevens, (ed), EEC and the Third World: a Survey (3), London, Hodder \& Stoughton

EEC, 1980, Report drawn up on behalf of the Comminee on Development and Cooperation on the European Community's contribution to the campaign against hunger in the world, European Parliament, Working Documents 1980-81, Doc 1-341/80, 29 August

-1981, Community Policy for the North-South Dialogue, Com(81) 68 final, Brussels, 7 May

-1982a, Memorandum on the Community's Development Policy, European Commission, Brussels, Com(82) 640 final

-1982b, Commission Communication to the Council on a Mediterranean Policy for the Enlarged Community, $\operatorname{Com}(82)$ 353 final, Brussels, 24 June

Green, R. H., 1973, 'Southern Africa: what kind of dialogue?' in C. Stevens, (ed), EEC and the Third World: a Survey (3), London, Hodder \& Stoughton

Lipton, M., 1983, 'African agricultural development: the EEC's new role', Development Policy Review, vol 1 no 1 , Overseas Development Institute, London, May

OAU, 1981, Lagos Plan of Action for the Economic Development of Africa 1980-2000, Addis Ababa

ODI, 1983, Briefing Paper - EEC Development Policy After Lomé, London, no 1, February

Moss, J. and J. Ravenhill, 1983, 'Trade between the ACP and EEC during Lomé I' in C. Stevens (ed), EEC and the Third World: a Survey (3), London, Hodder \& Stoughton

Shaw, T., 1979, 'EEC-ACP interactions and images as redefinitions of EurAfrica: exemplary, exclusive and/or exploitative?', Journal of Common Market Studies, vol XVIII no 2

Stevens, C., 1983a, 'New directions under Commissioner Pisani' in C. Stevens (ed), EEC and the Third World: $a$ Survey (3), London, Hodder \& Stoughton

-1983b, 'The EEC's year in Africa 1982', in C. Legum, (ed), Africa Contemporary Record 1982-83, Africana, New York, forthcoming

Svendsen, K. E., 1983, 'The view from Denmark' in C. Stevens (ed), EEC and the Third World: a Survey (3), London, Hodder \& Stoughton 